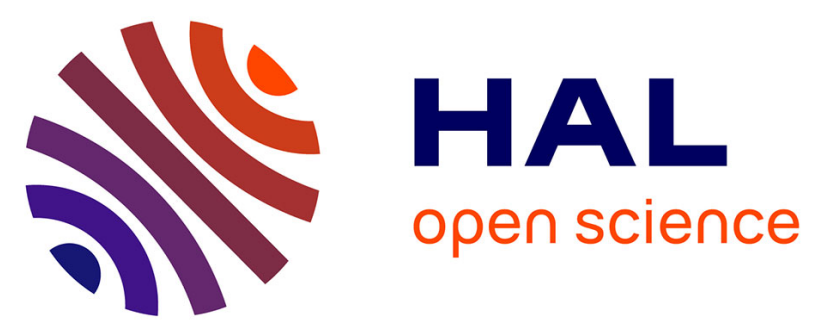

\title{
Two new bis-iridoids isolated from Scabiosa stellata and their antibacterial, antioxidant, anti-tyrosinase and cytotoxic activities
}

Meryem Lehbili, Abdulmagid Alabdul Magid, Jane Hubert, Ahmed Kabouche, Laurence Voutquenne-Nazabadioko, Jean-Hugues Renault, Jean-Marc Nuzillard, Hamid Morjani, Amin Abedini, Sophie C. Gangloff, et al.

\section{To cite this version:}

Meryem Lehbili, Abdulmagid Alabdul Magid, Jane Hubert, Ahmed Kabouche, Laurence VoutquenneNazabadioko, et al.. Two new bis-iridoids isolated from Scabiosa stellata and their antibacterial, antioxidant, anti-tyrosinase and cytotoxic activities. Fitoterapia, 2018, 125, pp.41 - 48. 10.1016/j.fitote.2017.12.018 . hal-03351296

\section{HAL Id: hal-03351296 \\ https://hal.univ-reims.fr/hal-03351296}

Submitted on 22 Sep 2021

HAL is a multi-disciplinary open access archive for the deposit and dissemination of scientific research documents, whether they are published or not. The documents may come from teaching and research institutions in France or abroad, or from public or private research centers.
L'archive ouverte pluridisciplinaire HAL, est destinée au dépôt et à la diffusion de documents scientifiques de niveau recherche, publiés ou non, émanant des établissements d'enseignement et de recherche français ou étrangers, des laboratoires publics ou privés. 
Two new bis-iridoids isolated from Scabiosa stellata and their antibacterial, antioxidant, anti-tyrosinase and cytotoxic activities

Meryem Lehbilia,b, Abdulmagid Alabdul Magid ${ }^{\mathrm{b},}$, Jane Hubert ${ }^{\mathrm{b}}$, Ahmed Kabouche $^{\mathrm{a}}$, Laurence Voutquenne-Nazabadioko $^{\mathrm{b}}$, Jean-Hugues Renault ${ }^{\mathrm{b}}$, Jean-Marc Nuzillard $^{\mathrm{b}}$, Hamid Morjani $^{\mathrm{c}}$, Amin Abedini ${ }^{\mathrm{b}, \mathrm{d}}$, Sophie C. Gangloff ${ }^{\mathrm{d}}$, Zahia Kabouche $^{\mathrm{a}}$

${ }^{a}$ Université des frères Mentouri-Constantine, Département de chimie, Laboratoire d'Obtention des Substances Thérapeutiques (LOST), Campus Chaabet-Ersas, 25000 Constantine, Algeria

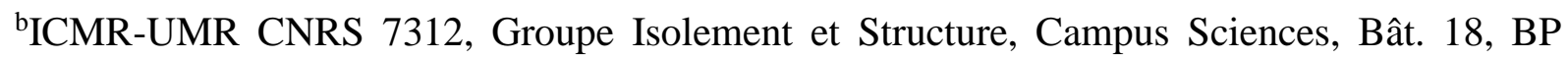
1039, 51687 Reims, France

${ }^{\mathrm{c}}$ MEDyC UMR CNRS 7369, URCA, Faculté de Pharmacie, SFR CAP Santé, 1, rue du Maréchal-Juin, 51096 Reims, France

${ }^{\text {d} E A ~} 4691$ «Biomatériaux et inflammation en site osseux», Laboratoire de microbiologie, UFR de pharmacie, 1, rue du Maréchal-Juin, 51096 Reims, France

* Corresponding author.

E-mail address: abdulmagid.alabdulmagid@univ-reims.fr (A. Alabdul Magid) 


\begin{abstract}
This study presents the chemical profile investigation of a $70 \%$ ethanol extract obtained from Scabiosa stellata, a medicinal herbaceous traditionally used to treat heel cracks. $\mathrm{A}^{13} \mathrm{C}$ NMRbased dereplication methodology was firstly applied on centrifugal partition chromatographygenerated fractions in order to quickly identify the major compounds of the extract. The dereplication process was then completed by semi-preparative high-performance liquid chromatography in order to identify unknown or minor compounds. Two new bis-iridoids, namely 7-O-caffeoyl-sylvestroside I (1) and 7-O-(p-coumaroyl)-sylvestroside I (2), together with ten known compounds (3-12) were isolated. Their structures were elucidated by spectroscopic methods including NMR and HR-ESI-MS. The antibacterial, anti-tyrosinase and DPPH radical scavenging activities of the crude extract, fractions, and isolated compounds were evaluated. A significant antibacterial activity was observed for nine isolated compounds, particularly $\mathbf{1}$ and $\mathbf{2}$ which yielded MIC values of $31.2 \mu \mathrm{g} / \mathrm{mL}$ against Enterococcus faecalis and $62.5 \mu \mathrm{g} / \mathrm{mL}$ against Staphylococcus epidermidis. The cytotoxic activity of these new bis-iridoids was evaluated on a fibrosarcoma cell line (HT1080) and only compound 1 exhibited a moderate cytotoxic activity ( $\mathrm{IC}_{50} 35.9 \mu \mathrm{g} / \mathrm{mL}$ ).
\end{abstract}


Keywords: Scabiosa stellata; Caprifoliaceae; Bis-iridoid glucoside; Antibacterial activity; Cytotoxic activity; dereplication.

\section{Introduction}

The genus Scabiosa belongs to the Caprifoliaceae family and comprises about 100 species. The majority of Scabiosa species occurs in the Mediterranean region [1] and among them 12 species grows in Algeria [2]. In Catalonia (Spain), the decoction of the aerial part of $S$. columbaria is traditionally used against diphtheria [3]. In Algeria, S. arvensis is used in folk medicine against diarrhea, inflammation, microbial infections and skin disorders [4]. In moroccan folk medicine, the leaves and flowers of S. stellata are used against heel cracks [5]. Many extracts obtained from Scabiosa species have already demonstrated antibacterial activities, such as S. atropurpurea [6], S. hymettia [7], S. columbaria [8], or S. arenaria [9]. The extracts of S. arenaria and S. tschiliensis have shown antioxidant properties [10,11]. Up to date, chemical investigations of Scabiosa species have mainly revealed the presence of saponins [12,13], flavonoids, and coumarins [14]. Previous studies have also reported that the genus Scabiosa characteristically contains bis- and mono-iridoid glucosides $[15,16]$.

Scabiosa stellata Cav., known with the common name starflower pincushions, is an herbaceous, bristly-hairy annual plant $(20-60 \mathrm{~cm})$. The lower leaves are 7-12 cm long, spoonshaped in outline, tapered at the base, the margins with blunt teeth irregular in size and placement. The outer florets are light gray-blue, irregularly shaped. The central florets are smaller and subtended each by a rounded translucent bract with a green midrib [4]. In this work, we have investigated the chemical profile of S. stellata and the antibacterial, tyrosinase inhibitory, DPPH radical scavenging and cytotoxic activities of the crude extract, fractions and isolated compounds. 


\section{Results and discussion}

The antibacterial activity of the $70 \% \mathrm{EtOH}$ extract obtained from the whole plant S. stellata was evaluated against 22 micro-organisms including 17 Gram-positive and Gram-negative bacteria and 5 yeasts. The MIC determination method in solid media was used [17]. The results are presented in Table 1 . The highest antimicrobial activity was observed against Streptococcus pyogenes (MIC $1.2 \mathrm{mg} / \mathrm{mL}$ ), whereas a low to moderate antimicrobial activity was observed against Bacillus subtilis (MIC $10 \mathrm{mg} / \mathrm{mL}$ ), Staphylococcus epidermidis, and Micrococcus luteus (MIC $2.5 \mathrm{mg} / \mathrm{mL}$ ). Regarding antifungal activity, the crude extract showed a moderate activity (MIC 2.5 to $5 \mathrm{mg} / \mathrm{mL}$ ). A moderate DPPH radical scavenging activity was also observed for this extract ( $\mathrm{IC}_{50} 86.0 \mu \mathrm{g} / \mathrm{mL}$ ), as well as a moderate tyrosinase inhibitory activity when tested on an in vitro mushroom tyrosinase assay (40\% inhibition at $1.33 \mathrm{mg} / \mathrm{mL}$ ) (Table 2).

In order to isolate potentially active compounds, a bioassay-guided fractionation strategy was applied throughout the separation procedure. The $70 \%$ ethanol extract of the whole plant $S$. stellata was subjected to a Diaion HP-20 column, eluting with 0\%, 25\%, 50\%, $75 \%$ and 100\% $\mathrm{MeOH}$, yielding five fractions (A-E, respectively). These fractions were evaluated for their antimicrobial, antioxidant and anti-tyrosinase activities (Tables 1 and 2). Fraction C exhibited the best antimicrobial activity against the 22 microorganisms (MIC 1.2 to $10 \mathrm{mg} / \mathrm{mL}$ ). Whereas fraction $\mathrm{B}$ was active only against the gram-positive bacteria (except Listeria innocua) and yeasts (MIC 0.6 to $2.5 \mathrm{mg} / \mathrm{mL}$ ) (Table 1). Fractions B and C showed also the best DPPH radical scavenging activity ( $\mathrm{IC}_{50} 48.7$ and $25 \mu \mathrm{g} / \mathrm{mL}$, respectively) (Table 2). Fraction $\mathrm{C}$ showed also a significant anti-tyrosinase activity ( $\mathrm{IC}_{50} 1.33 \mathrm{mg} / \mathrm{mL}$ ) and was slightly less active than fraction $\mathrm{D}\left(\mathrm{IC}_{50} 1 \mathrm{mg} / \mathrm{mL}\right.$ ) (Table 2). Therefore, the chemical profiles of fractions $\mathrm{B}$ and $\mathrm{C}$ were investigated in order to determine which compounds were 
responsible for these activities (Figure 1). Fractions B (2 g) and C (3 g) were subjected separately to CPC fractionation. The biphasic solvent system $\mathrm{M} t \mathrm{BE} / \mathrm{CH}_{3} \mathrm{CN} /$ water $(3 / 3 / 4$, $\mathrm{v} / \mathrm{v} / \mathrm{v})$ was selected to recover moderately polar compounds. After pooling the collected fractions on the basis of TLC profile similarities, adjacent sub-fractions $B_{1}-B_{23}$ and $C_{1}-C_{21}$ containing simplified mixtures or even pure compounds were obtained. Fractions $B_{1}-B_{23}$ and $\mathrm{C}_{1}-\mathrm{C}_{21}$ were all analyzed by ${ }^{13} \mathrm{C}-\mathrm{NMR}$ for dereplication [18]. Automatic peak picking and binning of ${ }^{13} \mathrm{C}$ signals across spectra resulted in two tables (one table for each CPC separation of B and C) which were independently submitted to Hierarchical Clustering Analysis (HCA) for pattern recognition. In this way, statistical correlations between ${ }^{13} \mathrm{C}$ NMR signals belonging to individual structures within the fraction series were visualized as "chemical shift clusters" on the resulting two-dimensional HCA correlation heat maps in front of the corresponding dendrograms. As illustrated in Figure 2, several well-defined clusters were intensely colored in yellow. After entering the chemical shift values of cluster 1 located in sub-fractions $\mathrm{B}_{4-8}$ and $\mathrm{C}_{7-14}$ into the database, the molecular structure of isoorientin (8) [19] was proposed. By means of the same database search strategy, cluster 2 present in subfractions $\mathrm{B}_{2-4}$ and $\mathrm{C}_{3-6}$ was identified as hyperin (10) [20], cluster 3 present in sub-fractions $\mathrm{B}_{20-23}$ and $\mathrm{C}_{11-14}$ was identified as eustomoruside (6) [21], cluster 4 present in sub-fractions $\mathrm{C}_{8 \text { - }}$ 9 corresponded to a bis-iridoid structure containing loganic acid and caffeic acid moieties, cluster 5 present in sub-fractions $B_{19-22}$ and $C_{15-21}$ was identified as sweroside (5) [22], cluster 6 present in sub-fractions $\mathrm{C}_{6-8}$ was identified as swertiajaponin (9) [19]. Cluster 7 present in sub-fractions $\mathrm{C}_{2-3}$ corresponded to a mixture of 3,5-dicaffeoylquinic acid (11) and 4,5dicaffeoylquinic acid (12) [11]. Cluster 8 present in sub-fractions $\mathrm{B}_{13-15}$ corresponded to eustomoside (7) [23]. Cluster 9 present in sub-fractions $\mathrm{B}_{9}-\mathrm{B}_{12}$ was identified as caffeic acid. For the sub-fractions $\mathrm{B}_{4-9}, \mathrm{~B}_{20-23}$ and $\mathrm{C}_{8-9}$, the database proposed a complex mixture of bisiridoid derivatives, partially composed of loganin, demethylsecologanol and sweroside units, 
which could not be identified unambiguously (cluster 10). Further purifications of the fractions containing the products corresponding to the remaining unidentified clusters were performed using silica gel flash chromatography, RP-18 flash chromatography and semipreparative RP-18 HPLC, leading to the identification of two previously undescribed bisiridoid glucosides (1-2) and two known bis-iridoid glucosides; sylvestroside I (3) [24] and septemfidoside (4) [25] (Figure 1).

Compound 1 was obtained as white amorphous powder with a molecular formula of $\mathrm{C}_{42} \mathrm{H}_{54} \mathrm{O}_{22}$, deduced from the positive HR-ESI-MS analysis $\left(\mathrm{m} / z\right.$ 933.2997, $\left.[\mathrm{M}+\mathrm{Na}]^{+}\right)$. The IR spectrum indicated the presence of hydroxyl groups $\left(3420 \mathrm{~cm}^{-1}\right)$ and $\alpha, \beta$-unsaturated ester carbonyl groups $\left(1697 \mathrm{~cm}^{-1}\right)$. The UV spectrum showed the characteristic absorption of $\beta$ alkoxyacrylic acid or its ester at $228 \mathrm{~nm}$ and absorption at $326 \mathrm{~nm}$ characteristic of a cinnamic acid derivatives. The ${ }^{1} \mathrm{H}$ and ${ }^{13} \mathrm{C}$ NMR spectroscopic data of compound $\mathbf{1}$ showed two distinct parts, units A and B (Fig. 1). The ${ }^{1} \mathrm{H}$ NMR spectrum showed signals for unit A that indicated the presence of an olefinic proton $\beta$-alkoxyacrylic acid at $\delta_{\mathrm{H}} 7.42(\mathrm{~s}, \mathrm{H}-3 \mathrm{a})$, a set of three protons on vinyl group at $\delta_{\mathrm{H}} 5.84(\mathrm{ddd}, J=17.3,10.3,8.7 \mathrm{~Hz}, \mathrm{H}-8 \mathrm{a}), 5.36(\mathrm{~d}, J=17.3 \mathrm{~Hz}, \mathrm{H}-$ $\left.10 \mathrm{a}_{1}\right)$ and $5.30\left(\mathrm{~d}, J=10.3 \mathrm{~Hz}, \mathrm{H}-10 \mathrm{a}_{2}\right)$, and an acetal proton at $\delta_{\mathrm{H}} 5.60(\mathrm{~d}, J=6.5 \mathrm{~Hz}, \mathrm{H}-1 \mathrm{a})$ which were characteristic of a secoiridoid moiety. The ${ }^{13} \mathrm{C}$ NMR, spectrum showed signals for carboxyl carbon $\left(\delta_{\mathrm{C}} 167.8, \mathrm{C}-11 \mathrm{a}\right)$, two alkenyl carbons $\left[\delta_{\mathrm{C}} 151.3(\mathrm{C}-3 \mathrm{a})\right.$ and $110.4(\mathrm{C}-4 \mathrm{a})$ due to the $\beta$-alkoxyacrylic ester group, and two others $\delta_{\mathrm{C}} 134.3(\mathrm{C}-8 \mathrm{a})$ and $118.2(\mathrm{C}-10 \mathrm{a})$ due to the vinyl group], one acetal carbon $\left(\delta_{\mathrm{C}} 96.3, \mathrm{C}-1 \mathrm{a}\right)$ and one hydroxyl-methyl carbon $\left(\delta_{\mathrm{C}}\right.$ 62.7, C-7a). 2D-NMR analysis indicated that unit A was an open form of the lactone moiety of sweroside. Furthermore, two anomeric protons resonances corresponding to $O$-linked sugars were observed in the ${ }^{1} \mathrm{H}$ NMR spectrum of $\mathbf{1}$ as two doublets at $\delta_{\mathrm{H}} 4.74(J=7.9 \mathrm{~Hz})$ and $4.68(J=7.9 \mathrm{~Hz})$. The sugar units were elucidated as two $\beta$-D-glucopyranoses [glc-A $\left(\delta_{\mathrm{H}-}\right.$ $1^{\prime} 4.74$ and $\left.\delta_{\mathrm{C}-1^{\prime}} 96.8\right)$ and glc-B $\left(\delta_{\mathrm{H}-1^{\prime \prime \prime}} 4.68\right.$ and $\left.\delta_{\mathrm{C}-1^{\prime \prime \prime}} 96.8\right)$ (Table 3$)$ based on the results of 
the acid hydrolysis of fraction $\mathrm{C}$ from which compound $\mathbf{1}$ was obtained, by the magnitudes of their $J_{1,2}$ coupling constants, interpretation of COSY, HSQC and HMBC spectra, and by comparing the ${ }^{13} \mathrm{C}$ NMR chemical shifts with those of related systems reported in the literature [26]. The glc-A unit was linked to $\mathrm{C}-1 \mathrm{a}$ as deduced from the long-range correlation observed between $\mathrm{H}-1^{\prime}$ and $\mathrm{C}-1 \mathrm{a}$ in the HMBC spectrum. The spectroscopic data of unit A were almost identical to demethylsecologanol [22,27,28] except for the low-frequency shift of $\mathrm{H}-7 \mathrm{a}\left(\delta_{\mathrm{H}} 4.21\right.$ and 4.26$)$ and $\mathrm{C}-7 \mathrm{a}\left(\delta_{\mathrm{C}} 62.7\right)$ and the high-frequency shift of C-11a $\left(\delta_{\mathrm{C}} 167.8\right)$. In the ${ }^{1} \mathrm{H}$ NMR spectrum of $\mathbf{1}$, a set of signals belonging to a $E$-caffeoyl moiety was detected with two coupled trans double-bond protons $\left[\delta_{\mathrm{H}} 6.24, \mathrm{H}-8^{\prime \prime}\right.$ and $7.55, \mathrm{H}-7^{\prime \prime}$, each $\mathrm{d}, J=16.0$ $\mathrm{Hz}]$ and three coupled aromatic protons $\left[\delta_{\mathrm{H}} 6.80\left(\mathrm{~d}, J=8.1 \mathrm{~Hz}, \mathrm{H}-5^{\prime \prime}\right), 6.96(\mathrm{dd}, J=8.1,2.0\right.$ $\left.\mathrm{Hz}, \mathrm{H}-6^{\prime \prime}\right)$ and $\left.7.05\left(\mathrm{~d}, J=2.0 \mathrm{~Hz}, \mathrm{H}-2^{\prime \prime}\right)\right]$. The presence of an $E$-caffeoyl moiety was evident by the connectivities observed in the HMBC spectrum between the trans double-bond and the $1,3,4$-substituted aromatic ring as well as to an ester carbonyl ( $\left.\delta \mathrm{C} 167.9, \mathrm{C}-9^{\prime \prime}\right)$ and its ${ }^{1} \mathrm{H}$ and ${ }^{13} \mathrm{C}$ resonances were assigned using 2D-NMR experiments (COSY, HSQC, and HMBC) (Table 3). An HMBC correlation was observed between $\mathrm{H}-7 \mathrm{a}$ and the carbonyl carbon C-9", indicating that demethylsecologanol was esterified by the E-caffeoyl moiety. Thus, unit A was identified as grandifloroside [29]. The second half, unit B, was easily assigned to a loganic acid-type iridoid [22,27,28] due to a methyl group at $\delta_{\mathrm{H}} 1.10(\mathrm{~d}, J=6.9 \mathrm{~Hz}, \mathrm{H}-10 \mathrm{~b})$, olefinic signal at $\delta_{\mathrm{H}} 7.53(\mathrm{~s}, \mathrm{H}-3 \mathrm{~b})$ together with $\delta_{\mathrm{C}} 152.3,111.6$ and 166.9 which were ascribed to $\mathrm{C}-3 \mathrm{~b}, \mathrm{C}-4 \mathrm{~b}$ and $\mathrm{C}-11 \mathrm{~b}$, respectively (Table 3). This was verified by the correlations in ${ }^{1} \mathrm{H}-{ }^{1} \mathrm{H}$ COSY spectrum observed between the protons signals at $\delta_{\mathrm{H}} 3.14(\mathrm{H}-$ 5b), $2.08(\mathrm{H}-9 \mathrm{~b}), 5.28(\mathrm{H}-1 \mathrm{~b})$ and $2.19(\mathrm{H}-8 \mathrm{~b})$, between the methyl group at $\delta_{\mathrm{H}} 1.10(\mathrm{H}-10 \mathrm{~b})$ and $\mathrm{H}-8 \mathrm{~b}$ and between signal at $\delta_{\mathrm{H}} 5.24(\mathrm{H}-7 \mathrm{~b})$, and $\mathrm{H}-8 \mathrm{~b}$. The structure of loganic acid moitiey was confirmed by the HMBC correlations observed between H-3b/C-1b, C-4b, C-5b and $\mathrm{C}-11 \mathrm{~b}, \mathrm{H}-7 \mathrm{~b} / \mathrm{C}-5 \mathrm{~b}$ and $\mathrm{H}-1 \mathrm{~b} / \mathrm{C}-10 \mathrm{~b}$ and the anomeric carbon $\mathrm{C}-1^{\prime \prime \prime}$ of Glc $\mathrm{B}$. 
Additionally, in the HMBC spectrum, the proton signal at $\delta_{\mathrm{H}} 7.53(\mathrm{H}-3 \mathrm{~b}), 3.68\left(-\mathrm{OCH}_{3}, \mathrm{H}-\right.$ $12 b)$ and $3.14(\mathrm{H}-5 \mathrm{~b})$ showed long-range correlations with the carbon resonance at $\delta_{\mathrm{C}} 166.9$ (C-11b) indicating the location of a methoxy group at $\mathrm{C}-11 \mathrm{~b}$. The spectroscopic data of unit $\mathrm{B}$ were almost identical to loganin [28,29] except for the downfieled shifts of $\mathrm{H}-7 \mathrm{~b}\left(\delta_{\mathrm{H}} 5.24\right)$ and $\mathrm{C}-7 \mathrm{~b}\left(\delta_{\mathrm{C}} 77.0\right)$. The connectivity between $\mathrm{A}$ and $\mathrm{B}$ units was found to be an ester linkage between the $\mathrm{C}-7 \mathrm{~b}$ hydroxyl group of unit $\mathrm{B}$ and the carboxyl group $(\mathrm{C}-11 \mathrm{a})$ as deduced by the HMBC correlation observed between $\mathrm{H}-7 \mathrm{~b}$ and $\mathrm{C}-11 \mathrm{a}$. The relative configuration of $\mathbf{1}$ was further determined on the basis of coupling constants and by the ROESY experiment. The ROESY correlations of $\delta_{\mathrm{H}} 2.95(\mathrm{H}-5 \mathrm{a})$ with $2.72(\mathrm{H}-9 \mathrm{a}), 2.08(\mathrm{H}-9 \mathrm{~b})$ with $1.10(\mathrm{H}-10 \mathrm{~b}), 3.14$ $(\mathrm{H}-5 \mathrm{~b})$ with $2.08(\mathrm{H}-9 \mathrm{~b})$ and $5.24(\mathrm{H}-7 \mathrm{~b})$ with $2.19(\mathrm{H}-8 \mathrm{~b})$ revealed the relative configuration of $\mathbf{1}$. Therefore, the structure of $\mathbf{1}$ was elucidated as 7-O-(E-caffeoyl)-sylvestroside I shown in Fig. 1 and differs from sylvestroside I, reported in Dipsacus laciniatus [24], with an additional E-caffeoyl group at C-7a.

Compound 2 displayed an $[\mathrm{M}+\mathrm{Na}]^{+}$ion peak at $\mathrm{m} / \mathrm{z}$ 917.3063, corresponding to the molecular formula $\mathrm{C}_{42} \mathrm{H}_{54} \mathrm{O}_{21}$ (calcd for $\mathrm{C}_{42} \mathrm{H}_{54} \mathrm{O}_{21} \mathrm{Na}, 917.3055$ ), suggesting the lack of one hydroxyl group compared to 1 . Comparison of ${ }^{1} \mathrm{H}$ and ${ }^{13} \mathrm{C}$ NMR values and the analysis of the ${ }^{1} \mathrm{H}-{ }^{1} \mathrm{H}-$ COSY, ROESY, HSQC and HMBC showed that $\mathbf{1}$ and $\mathbf{2}$ contained the same-skeleton (sylvestroside I) (Table 3). Thus, the difference between $\mathbf{1}$ and $\mathbf{2}$ should be located at the cinnamoyl derivative substituant. This latter was represented on the ${ }^{1} \mathrm{H}$ NMR spectrum by two trans-coupled double-bond protons at $\delta_{\mathrm{H}} 7.61$ and $6.30($ each $1 \mathrm{H}, \mathrm{d}, J=16.0 \mathrm{~Hz})$ assignable to $\mathrm{H}-7 "$ and H-8", respectively and four aromatic protons at $\delta_{\mathrm{H}} 7.47$ and 6.83 (each $2 \mathrm{H}, \mathrm{d}, J=$ $8.6 \mathrm{~Hz})$ assignable to $\mathrm{H}-2^{\prime \prime} / 6^{\prime \prime}$ and $\mathrm{H}-3^{\prime \prime} / 5^{\prime \prime}$ respectively, as well as to an ester carbonyl $\left(\delta_{\mathrm{C}}\right.$ 167.9) in the ${ }^{13} \mathrm{C}$ NMR spectrum. These data were consistent with the presence of an $E$ coumaroyl moiety (Table 1) [30] and its ${ }^{1} \mathrm{H}$ and ${ }^{13} \mathrm{C}$ resonances were assigned using 2D-NMR experiments (COSY, HSQC, and HMBC). The coumaroyl moiety was linked to the C-7a of 
the seco-loganin moiety as deduced from the HMBC correlation between the $\mathrm{H}-7 \mathrm{a}\left(\delta_{\mathrm{H}} 4.21\right.$ and 4.26) and the carbonyl carbon of coumaroyl group ( $\left.\delta_{\mathrm{H}} 167.9, \mathrm{C}-9^{\prime \prime}\right)$. Thus, the structure of compound 2 was concluded to be 7-O-(E-p-coumaroyl)-sylvestroside I as shown in Fig.1.

In order to screen the antibacterial potential of the compounds 1-12 isolated from the active fractions B and C, a bioautography assay was applied on a sensitive strain of Staphylococcus aureus (S. aureus CIP 53.154). S. aureus is a Gram-positive cocci bacterium frequently found on the skin and in the respiratory tract, and can be responsible for nosocomial infections. Compounds 1-4, 6, 8, 9, 11 and 12 were the only active compounds as revealed by the white inhibition zones observed on the TLC plate around the compound spots. A serial liquid dilution technique in 96-well microtiter plates was used to determine the minimum inhibitory concentration (MIC) of these eight active compounds against Enterococcus faecalis ATCC 1034, Staphylococcus aureus CIP 53.154, Escherichia coli CIP 54.127, Staphylococcus epidermidis, and Pseudomonas aeruginosa ATCC 9027 (Table 4). The results showed a good inhibitory effect of compounds 1 and 2 against E. faecalis (MIC $31.2 \mu \mathrm{g} / \mathrm{mL}$ ), S. epidermidis (MIC $31.2 \mu \mathrm{g} / \mathrm{mL}$ ), and S. aureus (MIC $62.5 \mu \mathrm{g} / \mathrm{mL}$ ). Compound 6 exhibited a good inhibitory effect against E. faecalis and S. aureus (MIC $62.5 \mu \mathrm{g} / \mathrm{mL}$ ). Only compound 3 showed an antibacterial activity against $E$. coli in addition to $S$. aureus (MIC $62.5 \mu \mathrm{g} / \mathrm{mL}$ ). Compounds 4, 8, 9 and 11 showed a low antibacterial activity against the five tested bacteria with MIC values ranging from 125 to $500 \mu \mathrm{g} / \mathrm{mL}$ (Table 4).

All isolated compounds (1-12) were then evaluated for their DPPH radical scavenging effect. As summarized in table 2, only compounds 6, 7, 8 and 10 exhibited $\mathrm{IC}_{50}$ values ranging from $7.1 \pm 0.2$ to $16.0 \pm 0.4 \mu \mathrm{g} / \mathrm{mL}$ whereas for the other compounds the $50 \% \mathrm{DPPH}$ inhibition could not been reached even at $200 \mu \mathrm{g} / \mathrm{mL}$. These values were very close to that obtained with ascorbic acid used as positive control ( $\left.\mathrm{IC}_{50} 6.3 \pm 0.1 \mu \mathrm{g} / \mathrm{mL}\right)$. Compounds 1-12 were also evaluated for their mushroom tyrosinase inhibitory activity. None of the isolated compound 1- 
12 was active at the concentration of $665 \mu \mathrm{g} / \mathrm{mL}$ (Table 2). Finally, the cytotoxic activity of previously undescribed compounds $\mathbf{1}$ and $\mathbf{2}$ was evaluated in vitro using a fibrosarcoma cell line (HT1080). Only compound $\mathbf{1}$ exhibited a moderate cytotoxic activity with an $\mathrm{IC}_{50}$ value of $35.9 \pm 0.06 \mu \mathrm{g} / \mathrm{mL}$, while compound 2 was inactive $\left(\mathrm{IC}_{50}>100 \mu \mathrm{g} / \mathrm{mL}\right)$.

\section{Experimental}

\subsection{General experimental procedures}

Optical rotations of pure compounds were measured in $\mathrm{CH}_{3} \mathrm{OH}$ using a Perkin-Elmer 341 Polarimeter. HR-ESI-MS experiments were performed using a Micromass Q-TOF micro instrument (Manchester, UK). Thin-layer chromatography (TLC) was carried out on silica gel $60 \mathrm{~F}_{254}$ pre-coated aluminum plates $\left(0.2 \mathrm{~mm}\right.$, Merck), using the system $\mathrm{CHCl}_{3} / \mathrm{MeOH} / \mathrm{H}_{2} \mathrm{O}$ $(14 / 6 / 1, v / v)$ as the mobile phase. The spots were visualized under UV light (254 and $366 \mathrm{~nm})$ and sprayed with $50 \% \mathrm{H}_{2} \mathrm{SO}_{4}$ followed by heating. Flash chromatography was carried out on a Grace Reveleris system equipped with dual UV and ELSD detection and using Grace® cartridges (Silica gel or RP-C 18 ).

\subsection{Plant material}

The plant Scabiosa stellata Cav. (Caprifoliaceae) was collected from Djebel El-Ouahch at Constantine (North eastern of Algeria) in June 2015 and authenticated by Mr. Kamel Kabouche. A Voucher specimen (LOST.Cs.06.15) was deposited at the Constantine University Herbarium (Algeria).

\subsection{Extraction and isolation}

The dried and powdered S. stellata whole plant $(653 \mathrm{~g})$ was macerated in $70 \% \mathrm{EtOH}(3 \times 3 \mathrm{~L}$, $24 \mathrm{~h}$ ) at room temperature. The combined $70 \% \mathrm{EtOH}$ solution was concentrated under vacuum to provide the $70 \%$ EtOH extract $(118 \mathrm{~g})$. This extract was dissolved in water $(1 \mathrm{~L})$ and then subjected to a Diaion HP-20 macroporous resin column $(4.3 \times 40 \mathrm{~cm}$, internal diameter), 
eluting successively with a mixture of $\mathrm{MeOH}-\mathrm{H}_{2} \mathrm{O}(2 \mathrm{~L}$ each for $0 \%, 25 \%, 50 \%, 75 \%$ and $100 \% \mathrm{MeOH}$ solution, ) to afford five fractions A-E, respectively.

\subsubsection{Centrifugal partition chromatography}

Centrifugal partition chromatography (CPC) experiments were carried out using a lab-scale FCPE300® column of $303 \mathrm{~mL}$ capacity (Rousselet Robatel Kromaton, Annonay, France) containing 7 circular partition disks and engraved with a total of 231 partition twin-cells $(\approx 1$ mL per twin cell). The liquid phases were pumped by a KNAUER Preparative 1800 V7115 pump (Berlin, Germany). The column was coupled on-line with a UVD $170 \mathrm{~S}$ detector set at 210, 254, 280 and $366 \mathrm{~nm}$ (Dionex, Sunnivale, CA, USA). Fractions of $15 \mathrm{~mL}$ were collected by a Pharmacia Superfrac collector (Uppsala, Sweden). The solvent system was MtBE / $\mathrm{CH}_{3} \mathrm{CN} /$ water in the ratio 3/3/4 (v/v/v). The column was filled with the lower phase of the biphasic solvent system at $500 \mathrm{rpm}$. The rotation speed was then increased up to $1200 \mathrm{rpm}$.

Fractions $\mathrm{B}$ and $\mathrm{C}$ were subjected separately to $\mathrm{CPC}$; each one was dissolved in $30 \mathrm{~mL}$ of a mixture of both lower phase $(20 \mathrm{~mL})$ and upper phase $(10 \mathrm{~mL})$. For the separation of fraction B (1.8 $\mathrm{g}$ injected), the upper phase of the biphasic solvent system was pumped for $100 \mathrm{~min}$ in the ascending mode at $20 \mathrm{~mL} / \mathrm{min}$. Then the column was extruded by pumping the organic phase in the descending mode at $20 \mathrm{~mL} / \mathrm{min}$. Fractions of $20 \mathrm{~mL}$ were collected over the whole experiment. For the separation of fraction C (3 g), the CPC method was identical, except for the extrusion step which was performed between 80 and 100 min. All fractions were analyzed by TLC and HPLC and then pooled, giving sub-fractions $\mathrm{B}_{1}-\mathrm{B}_{23}$ and $\mathrm{C}_{1}-\mathrm{C}_{21}$.

\subsubsection{NMR analyses and dereplication of the major metabolites}

As a first step in this developed ${ }^{13} \mathrm{C}$ NMR-based dereplication method [18], structures and names of metabolites already described in the genus Scabiosa were collected from the reports available in the literature. In total, 12 metabolites were found. The predicted ${ }^{13} \mathrm{C}$ NMR chemical shifts of each one was then stored into a local database already comprising 2700 
structures of natural compounds (NMR Workbook Suite 2012, ACD/Labs, Ontario, Canada). In the second step, all the sub-fractions of the both CPC experiments were dried under vacuum and each aliquot $(\approx 20 \mathrm{mg})$ was dissolved in $600 \mu \mathrm{L}$ of methanol- $d_{4}$ and analyzed by ${ }^{13} \mathrm{C}$ NMR. NMR spectra were recorded at $298 \mathrm{~K}$ on a Bruker Avance AVIII-600 spectrometer (Karlsruhe, Germany) equipped with a TXI cryoprobe. ${ }^{13} \mathrm{C}$ NMR spectra were acquired at 150.91 MHz. A standard zgpg pulse sequence was used with an acquisition time of $0.9 \mathrm{~s}$ and a relaxation delay of 3 s. For each sample, a total of 1024 scans were added to obtain a satisfactory signal-to-noise ratio. The spectral width was $240 \mathrm{ppm}$ and the receiver gain was set to the highest possible value. Spectra were then manually phased, baseline corrected using the TOPSPIN3.2 software (Bruker), and calibrated on the central resonance of methanol- $d_{4}(\delta$ $49.10 \mathrm{ppm})$.

The last step consisted in the binning of all ${ }^{13} \mathrm{C}$ NMR signals followed by the visualization of the whole dataset as a heat map. For this purpose, the absolute intensities of all ${ }^{13} \mathrm{C}$ NMR signals detected in the spectra of the fraction series were automatically collected and each resulting peak list was stored as a text file. The binning step was performed by using a locally developed computer script written in Python language. Its principle was to divide the ${ }^{13} \mathrm{C}$ spectral width (from 0 to $240 \mathrm{ppm}$ ) into regular chemical shift windows ( $\Delta \delta=0.2 \mathrm{ppm}$ ), and to associate the absolute intensity of each peak to the corresponding bin. The resulting table was imported into the PermutMatrix version 1.9.3 software (LIRMM, Montpellier, France) and submitted to Hierarchical Clustering Analysis (HCA) for data visualization. Then the chemical shifts clusters regrouped with the HCA were compared to a database to identify the compounds. In order to confirm the structures of the identified compounds, additional 1D and 2D NMR experiments $\left({ }^{1} \mathrm{H}\right.$ NMR, HSQC, HMBC, and $\left.{ }^{1} \mathrm{H}-{ }^{1} \mathrm{H}-\mathrm{COSY}\right)$.

\subsubsection{HPLC, Flash chromatography and column chromatography analyses}


Analytical HPLC experiments were performed using a Thermofisher Ultimate 3000 (Thermo Fischer Scientific, Villebon sur Yvette, France), equipped with a 4 ways pump LPG 3400 SD, an automatic injector WPS 3000 SL and a UV/Visible diode array detector 3000. The mobile phase was composed of $\mathrm{H}_{2} \mathrm{O}$ with TFA $\left(0.0025 \%\right.$ v/v) and $\mathrm{CH}_{3} \mathrm{CN}$. A gradient elution method was applied from $10 \%$ to $50 \%$ of $\mathrm{CH}_{3} \mathrm{CN}$ in 30 min with a flow rate of $1 \mathrm{~mL} / \mathrm{min}$. The chromatographic column used was a Kinetex $\mathrm{C}_{18}(4.6 \times 100 \mathrm{~mm} 2.6 \mu$, Phenomenex, France). A prepacked $\mathrm{RP}^{-\mathrm{C}_{18}}$ column (Phenomenex Luna $250 \times 15 \mathrm{~mm}, 5 \mu$ ) was used for semipreparative HPLC. The mobile phase consisted of $\mathrm{H}_{2} \mathrm{O}$ with TFA $(0.0025 \%)$ and $\mathrm{CH}_{3} \mathrm{CN}$ with a flow rate of $5 \mathrm{~mL} / \mathrm{min}$ and the chromatogram was monitored at 210, 254, 280 and $366 \mathrm{~nm}$. Sub-fractions $\mathrm{C}_{2-4}$ were purified through $\mathrm{RP}-\mathrm{C}_{18}$ semi-prep HPLC with gradient system (18$\left.45 \% \mathrm{CH}_{3} \mathrm{CN}, 25 \mathrm{~min}\right)$ to yield compounds $\mathbf{8}\left(t_{\mathrm{R}} 7.9,6 \mathrm{mg}\right), \mathbf{1 1}\left(t_{\mathrm{R}} 13.4,6 \mathrm{mg}\right)$ and $\mathbf{1 2}\left(t_{\mathrm{R}} 14.2\right.$, $16 \mathrm{mg}$ ). Compounds 1 ( $7 \mathrm{mg}$ ) and $2(23 \mathrm{mg})$ were purified by a flash chromatography from the sub-fraction $\mathrm{C}_{20-21}\left(293 \mathrm{mg}\right.$ ) on reversed phase using a gradient $10-50 \% \mathrm{CH}_{3} \mathrm{CN}$ in water as a mobile phase. Compounds $\mathbf{1 0}(36 \mathrm{mg})$ and $\mathbf{9}(7 \mathrm{mg})$ were obtained as a yellow precipitate from the subfractions $\mathrm{C}_{10}$ and $\mathrm{C}_{13}$ respectively. Sub-fractions $\mathrm{C}_{18}(398 \mathrm{mg})$ was subjected to flash chromatography over silica gel, eluted by gradient system of $\mathrm{CHCl}_{3}-\mathrm{MeOH}(10: 0-7: 3)$ to give compounds $3(15 \mathrm{mg})$ and 4 (3 mg). Compounds $5(4 \mathrm{mg}), 6(6 \mathrm{mg})$ and $7(5 \mathrm{mg})$ were obtained from sub-fractions $\mathrm{C}_{20}$ using both the same method and eluent as for the sub fraction $\mathrm{B}_{21-22 \text {. }}$

\subsection{7-O-(E-caffeoyl)-sylvestroside I (1)}

Yellowish solid; $[\alpha]_{\mathrm{D}}{ }^{25}-36.5$ (c $\left.0.23, \mathrm{MeOH}\right) ; \mathrm{UV}_{\max }(\mathrm{MeOH}): 228,326 ;{ }^{1} \mathrm{H}-$ and ${ }^{13} \mathrm{C}-\mathrm{NMR}$ data, see Table 3; HR-ESI-MS m/z: $933.2997[\mathrm{M}+\mathrm{Na}]^{+}$(calcd for $\mathrm{C}_{42} \mathrm{H}_{54} \mathrm{O}_{22} \mathrm{Na}$, 933.3004).

\subsection{7-O-(E-p-coumaroyl)-sylvestroside I (2)}


Yellowish solid; $[\alpha]_{\mathrm{D}}^{25}-77.2(c 0.25, \mathrm{MeOH})$; IR $(\mathrm{KBr}) v_{\max }\left(\mathrm{cm}^{-1}\right): 3420,1697 ; \mathrm{UV}_{\max }$ (MeOH): 228, 312; ${ }^{1} \mathrm{H}-$ and ${ }^{13} \mathrm{C}-\mathrm{NMR}$ data, see Table 3; HR-ESI-MS $m / z: 917.3063[\mathrm{M}+\mathrm{Na}]^{+}$ (calcd for $\mathrm{C}_{42} \mathrm{H}_{54} \mathrm{O}_{21} \mathrm{Na}, 917.3055$ ).

\subsection{Bioassay procedure}

\subsubsection{Antimicrobial Activity}

3.6.1.1. Antimicrobial screening of the 70\% EtOH extract and fractions A-E of S. stellata against a panel of 22 microbial strains.

The antimicrobial screening was performed on a total of 17 bacteria obtained from the Laboratory of Microbiology, faculty of pharmacy from the University of Reims ChampagneArdenne including the following Gram-positive bacteria: Bacillus subtilis, Enterococcus faecalis ATCC 1034, Staphylococcus aureus 8325-4, Staphylococcus aureus CIP 53.154, Micrococcus luteus, Listeria innocua, Streptococcus pyogenes and Staphylococcus epidermidis, and the following Gram-negative bacteria: Escherichia coli CIP 54.127, Enterobacter cloacae, Salmonella enterica, Serratia marcescens, Proteus vulgaris, Klebsiella pneumoniae, Providencia stuartii, Pseudomonas aeruginosa ATCC 9027, Shigella soneii, as well as five yeasts obtained from the Laboratory of Parasitology-Mycology (Transmission Vectorielle et Epidémio-surveillance des Maladies Parasitaires, EA 4688) of the University of Reims Champagne-Ardenne: Candida glabrata, C. tropicalis, C. kefyr, C. albicans and Cryptococcus neoformans. The 17 bacteria and 5 yeasts were incubated overnight at $37{ }^{\circ} \mathrm{C}$ in tubes containing Mueller-Hinton (MH) broth medium. The bacteria were then diluted with MH-broth by means of serial dilution to finally reach a concentration of $10^{5}$ bacteria/mL. The same process was performed for bacteria and yeasts. The minimum inhibitory concentration (MIC) of the crude ethanol extract of S. stellata was studied using MH agar in square Petri dishes seeded by multiple inoculators as described in a previous work [17,31]. The crude 
extract was tested at six final concentrations $(10,5,2.5,1.2,0.6$, and $0.3 \mathrm{mg} / \mathrm{mL})$ against the 22 microorganisms. The agar plates were incubated for $24 \mathrm{~h}$ at $37^{\circ} \mathrm{C}$. The activity was then visually estimated by the presence or absence of colonies. MIC values were recorded as the lowest concentrations of compounds enabling growth inhibition. Solvents were checked for absence of antimicrobial activity. Positive antimicrobial controls were used for bacteria (gentamicin and vancomycin) and yeasts (amphotericin B).

3.6.1.2. Evaluation of the antibacterial activity of the isolated compounds against Staphylococcus aureus by bioautography

As described in a previous work [31], an aliquot of each compound (2 mg) was solubilized in $1 \mathrm{~mL}$ methanol. A part of the resulting solutions $(25 \mu \mathrm{L})$ were spotted onto Merck $60 \mathrm{~F}_{254}$ precoated silica gel plates $(10 \times 10 \mathrm{~cm})$. Methanol and Gentamicin $(50 \mu \mathrm{g})$ were also spotted on the plates as negative and positive control, respectively. The TLC plates were directly dried without migration and sterilized. The plates, placed in square Petri dishes were then covered by Mueller-Hinton (MH) agar medium containing a Staphylococcus aureus 53.154 suspension of $10^{5}$ bacteria/mL. After incubation for $24 \mathrm{~h}$ at $37{ }^{\circ} \mathrm{C}$, bacterial growth was revealed by a 2 $\mathrm{mg} / \mathrm{mL}$ solution of thiazolyl blue tetrazolium bromide (MTT) and growth inhibition zones were measured. White stains indicated where reduction of MTT to the colored formazan did not take place due to the absence of bacterial growth.

3.6.1.3. MIC determination of the most active compounds against E. faecalis, S. aureus, E. coli, S. epidermis and P. aeruginosa by broth microdilution

A serial liquid dilution technique in 96-well microliter plates was used to determine the MIC values of the most promising compounds as revealed by bioautography [32]. For this purpose, nine concentrations of the most active fractions, from $500 \mu \mathrm{g} / \mathrm{mL}$ to $2 \mu \mathrm{g} / \mathrm{mL}$ were tested in 
presence of bacterial suspensions $\left(10^{5}\right.$ bacteria/mL $)$ giving a final volume of $200 \mu \mathrm{L}$ in $\mathrm{MH}$ media. Two wells were represented as bacteria culture control (positive control) and medium sterility control (negative control). The plates were incubated overnight at $37^{\circ} \mathrm{C}$, sprayed with a $0.2 \mathrm{mg} / \mathrm{mL}$ MTT solution and incubated again at $37{ }^{\circ} \mathrm{C}$ for $30 \mathrm{~min}$. Bacterial growth was indicated by a violet color whatever the color intensity, while bacterial growth inhibition was admitted only for wells which remained clear. MIC values were determined as the lowest concentrations of samples having an inhibitory effect on bacteria growth (clear wells).

\subsubsection{Free radical scavenging activity}

The antioxidant activity of crude extracts, fractions and purified compounds was measured in terms of hydrogen donating or radical scavenging ability using the stable radical DPPH method [33]. $5 \mu \mathrm{L}$ of different concentrations of the samples were added to $95 \mu \mathrm{L}$ of a DPPH solution $(158 \mu \mathrm{M}$, dissolved in $\mathrm{EtOH} 50 \%)$. The reaction proceeded for $30 \mathrm{~min}$ at $37^{\circ} \mathrm{C}$ on a 96-well microplate and the absorbance was then read at $515 \mathrm{~nm}$. The DPPH inhibition percentage was calculated as followed: \% inhibition $\left[\left(\mathrm{Ab}_{\text {control }}-\mathrm{A} \mathrm{b}_{\text {sample }}\right) / \mathrm{A} \mathrm{b}_{\text {control }}\right] \times 100$. A DPPH solution in EtOH 50\% was used as a control. The curve of the \% scavenging activity against the concentration of sample was prepared by MSExcel based program to obtain the $\mathrm{IC}_{50}$. Samples were prepared at concentrations of 100, 50, 25, 6.2 and $3.1 \mu \mathrm{g} / \mathrm{mL}$. Ascorbic acid was used as a positive control. All the tests were conducted in triplicate. Ascorbic acid was used as a positive control agent.

\subsubsection{Tyrosinase enzyme assay}

The tyrosinase inhibitory activity was determined according to the method described previously [34]. L-DOPA was used as the substrate in this experiment. Samples were prepared at concentrations of $400,100,50,25$ and $12.5 \mu \mathrm{g} / \mathrm{mL}$ in $10 \%$ DMSO in aqueous solution and 
$100 \mu \mathrm{L}$ of each concentration were added to 96-well plate and then $100 \mu \mathrm{L}$ of $135 \mathrm{U} / \mathrm{mL}$ fungal tyrosinase in phosphate buffer solution (PBS, pH 6.8) were added. After pre-incubation at $25^{\circ} \mathrm{C}$ for $10 \mathrm{~min}, 100 \mu \mathrm{L}$ of L-DOPA (0.5 mM, PBS pH 6.8) were added into 96-well plate. The reaction mixture was incubated for another $5 \mathrm{~min}$ at $25^{\circ} \mathrm{C}$. The amount of dopachrome in the mixture was determined by the measurement of the absorbance of each well at $475 \mathrm{~nm}$. Kojic acid was used as positive control agent. The inhibitory percentage of tyrosinase was calculated according to the following equation: \% inhibition $=\{[(A-B)-(C-D)] /(A-B)\} \times 100(A$ : $\mathrm{Ab}$ without test substance; $B: \mathrm{Ab}$ without test substance and tyrosinase; $C: \mathrm{Ab}$ with test substance; $D$ : Ab with test substance, but without tyrosinase). All the tests were conducted in triplicate and $\mathrm{IC}_{50}$ was determined by interpolation of concentration $\%$ inhibition curve obtained by MSExcel based program.

\subsubsection{Cell proliferation assay}

The fibrosarcoma cells (HT1080) were cultured in Minimum Essential Media (MEM) supplemented with $10 \%$ fetal bovine serum (FBS) and 1\% Penicillin Streptomycin (PS) at 37 ${ }^{\circ} \mathrm{C}$ with $5 \% \mathrm{CO}_{2}$ and harvested every three days for maintenance. Compounds $\mathbf{1}$ and $\mathbf{2}$ were dissolved in DMSO. For treatment, cells were plated at a density of $10^{4}$ cells $/ \mathrm{mL}$ in $24-$ well plates at $37^{\circ} \mathrm{C}$. After $24 \mathrm{~h}$, the culture medium was discarded and cells were treated with the compounds in a fresh culture medium at various concentrations for $72 \mathrm{~h}$, while the same dilution volume of DMSO was added in negative control wells. The concentration of DMSO did not exceed $0.1 \%$ to avoid significant toxicity on the tested cells. Therefore, the cells were washed once with $1 \mathrm{~mL}$ of D-PBS and then detached with $0.2 \%$ Trypsin/EDTA. Cell counting was carried out on a KOVA® slide and with a phase contrast microscope as indicated by the manufacturer. Cell growth was calculated in percentage as the fraction of cell number in 
treated and control cells. $\mathrm{IC}_{50}$ was determined as the concentration of each compound which induced $50 \%$ inhibition of cell growth.

\section{Conclusions}

Twelve compounds were identified and isolated from crude $70 \% \mathrm{EtOH}$ crude extract of $S$. stellata among them seven showed good to moderate inhibitory activity against $S$. aureus, $E$. coli, P. aeruginosa, E. faecalis and S. epidermidis. And only four compounds showed DPPH radical scavenging activity. A new bis-iridoid showed a cytotoxic activity against fibrosarcoma cell line (HT1080). All structures were unambiguously assigned based on NMR, HRESIMS data which afforded the new bis-iridoids (1-2) and known compounds 3-12 structures. Iridoids and bis-iridoids, found in a large number of plants of the Caprifoliaceae family and the major components were derived from loganin or secologanin with a sugar unit at C-1 and bis-iridoids heterodimers [11,35]. Interestingly; in the present work, all bis-iridoids (1-4) isolated from S. stellata were found to possess secoiridoid/iridoid-subtype skeletons, which are closely related to the bis-iridoids catleyoside isolated from Scabiosa variifolia [15] and dipsanoside C-G isolated from Dipsacus asper [36]. Also, sylvestroside I (3) was previously isolated from the genus Dipsacus [24]. This indicates a close relationship between the two genera Scabiosa and Dipsacus. Septemfidoside (4), eustomorusside (6) and eustomoside (7) are reported for the first time in the Caprifoliaceae family.

\section{Conflict of interest.}

The authors declare no conflict of interest

\section{Acknowledgements.}

The authors are grateful to MESRS Algeria for the PNE grant to Ms Meryem Lehbili, to CNRS, Conseil Régional de Champagne Ardenne (CRCA), Conseil Général de la Marne, 
Ministry of Higher Education and Research (MESR) in France, and to the PlANET CPER project for financial support. The authors warmly thank Chantal Grimplet for her technical assistance and Pr. Jérôme Depaquit for access to some of the microbial strains.

\section{Appendix A. Supplementary data.}

Supplementary data to this article can be found online at

\section{References}

[1] S.E. Carlson, H.P. Linder, M.J. Donoghue, The historical biogeography of Scabiosa (Dipsacaceae): implications for Old World plant disjunctions. J. Biogeogr. 39 (2012) 1086-1100.

[2] P. Quezel, S. Santa, New Flora of Algeria and the Southern Desert Regions, CNRS, Paris, 1963.

[3] M. Rigat, M.A. Bonet, S. Garcia, T. Garnatje, J. Valles, Studies on pharmaceutical ethnobotany in the high river Ter valley (Pyrenees, Catalonia, Iberian Peninsula), J. Ethnopharmacol. 113 (2007) 267-277.

[4] A. Chorfi, A. Ziriat, A. Bagot, S. Boulé, Illustrated guide of the Algerian flora. Wilaya d'Alger, Mairie de Paris. Délégation Générale aux Relations Internationales, Paris, 2012.

[5] J. Bammi, A. Douira, Medicinal plants of the achach forest in Morocco, Acta Botanica Malacitana 27 (2002) 131-145.

[6] R.W. Bussmann, A. Malca-García, D. Glenn, D. Sharon, G. Chait, D. Díaz, K. Pourmand, B. Jonat, S. Somogy, G. Guardado, C. Aguirr, R. Chan, K. Meyer, A. Kuhlman, A. Townesmith, J. Effio-Carbajal, F. Frías-Fernandez, M. Benito, Minimum inhibitory concentrations of medicinal plants used in Northern Peru as antibacterial remedies, J. Ethnopharmacol. 132 (2010) 101-108.

[7] C. Christopoulou, K. Graikou, I. Chinou, Chemosystematic value of chemical constituents from Scabiosa hymettia (Dipsacaceae), Chem. Biodiv. 5 (2008) 318-323. 
[8] S.F. Van Vuuren, D. Naidoo, An antimicrobial investigation of plants used traditionally in southern Africa to treat sexually transmitted infections, J. Ethnopharmacol. 103 (2010) $552-558$.

[9] B.M. Hlila, H. Mosbah, K. Majouli, A. Ben Nejma, H. Ben Jannet, M. Mastouri, M. Aouni, B. Selmi, Antimicrobial activity of Scabiosa arenaria Forssk. extracts and pure compounds using bioguided fractionation, Chem. Biodivers. 13 (2016) 1262-1272.

[10] B.M. Hlila, H. Mosbah, K. Mssada, H.B. Jannet, M. Aouni, B. Selmi, Acetylcholinesterase inhibitory and antioxidant properties of roots extracts from the Tunisian Scabiosa arenaria Forssk., Ind. Crops Prod. 67 (2015) 62-69.

[11] J. Wang, K. Liu, X. Li, K. Bi, Y. Zhang, J. Huang, R. Zhang, Variation of active constituents and antioxidant activity in Scabiosa tschiliensis Grunning from different stages, J. Food. Sci. Technol. 54 (2017) 2288-2295.

[12] T. Aykal, T. Panayir, D. Tasdemir, O. Sticher, I. Çalis, Triterpene saponins from Scabiosa rotata, Phytochemistry 48 (1998) 867-873.

[13] Q. Zheng, K. Koike, L.K. Han, H. Okuda, T. Nikaido, New biologically active triterpenoid saponins from Scabiosa tschiliensis, J. Nat. Prod. 67 (2004) 604-613.

[14] E.A. Garaev, I.S. Movsumov, M.I. Isaev, Flavonoids and oleanolic acid from Scabiosa caucasia, Chem. Nat. Compd. 44 (2008) 520-521.

[15] A. Papalexandrou, P. Magiatis, D. Perdetzoglou, A.L. Skaltsounis, I.B. Chinou, C. Harvala, Iridoids from Scabiosa variifolia (Dipsacaceae) growing in Greece. Biochem. Syst. Ecol. 31 (2003) 91-93.

[16] E. Polat, Ö. Alankus-Caliskan, T. Karayildirim, E. Bedir, Iridoids from Scabiosa atropurpurea L. subsp. maritima Arc. (L.), Biochem. Syst. Ecol. 38 (2010) 253-255.

[17] A. Abedini, S. Chollet, A. Angelis, N. Borie, J.M. Nuzillard, A.L. Skaltsounis, R. Reynaud, S.C. Gangloff, J.H. Renault, J. Hubert, Bioactivity-guided identification of 
antimicrobial metabolites in Alnus glutinosa bark and optimization of oregonin purification by Centrifugal Partition Chromatography, J Chromatogr B 1029:1030 (2016) 121-127.

[18] S.K. Oettl, J. Hubert, J.M. Nuzillard, H. Stuppner, J.H. Renault, J.M. Rollinger, Dereplication of depsides from the lichen Pseudevernia furfuracea by centrifugal partition chromatography combined to ${ }^{13} \mathrm{C}$ nuclear magnetic resonance pattern recognition, Anal. Chim. Acta. 846 (2014) 60-67.

[19] D. Davoust, M. Massias, D. Molho, Carbon-13 NMR investigation of flavonoid $C-\beta$-Dglucosides. Detection of a conformational equilibrium, Magn Reson Chem. 13 (1980) 218-219.

[20] C. Pereira, C.B. Barreto Júnior, R.M. Kuster, N.K. Simas, C.M. Sakuragui, A. Porzel, L. Wessjohann, Flavonoids and a neolignan glucoside from Guarea macrophylla (Meliaceae), Química Nova 35 (2012) 1123-1126.

[21] F.Y. Huang, J.J. Wu, G.P. Li, A New Secoiridoid Glycoside from Swertia cincta, Chinese Herbal Medicines 6 (2014) 73-75.

[22] D. Prasad, V. Juyal, R. Singh, V. Singh, G. Pant, M.S.M. Rawat, A new secoiridoid glycoside from Lonicera angustifolia, Fitoterapia 71 (2000) 420-424.

[23] M.E. Mpondo, J. Garcia, A. Chulia, Secoiridoid glucosides from Gentiana campestris, Phytochemistry 29 (1990) 1687-1688.

[24] M.A. Abdallah, Phenolic glucoside and other constituents of Dipsacus laciniatus, Phytochemistry 30 (1991) 28052806.

[25] I. Çalis, T. Irsoz, Septemfidoside: a new bis-iridoid diglucoside from Gentiana septemfida, J. Nat. Prod. 55 (I992) 385-388.

[26] P.K. Agrawal, NMR Spectroscopy in the structural elucidation of oligosaccharides and glycosides, Phytochemistry 31 (1992) 3307-3330. 
[27] M. Kitajima, N. Fujii, F. Yoshino, H. Sudo, K. Saito, N. Aimi, H. Takayama, Camptothecins and two new monoterpene glucosides from Ophiorrhiza Liukiuensis, Chem. Pharm. Bull. 53 (2005) 1355-1358.

[28] A. Kocsis, L.F. Szabo, B. Podanyi, New bis-iridoids from Dipsacus laciniatus, J. Nat. Prod. 56 (1993) 1486-1499.

[29] A. Itoh, K. Fujii, S. Tomatsu, C. Takao, T. Tanahashi, N. Nagakura, C.C. Chen, Six secoiridoid glucosides from Adina racemose, J. Nat. Prod. 66 (2003) 1212-1216.

[30] D.P.A. Gossan, A. Alabdul Magid, P.A. Yao-Kouassi, A. Ahibo Coffy, D. Harakat, L. Voutquenne-Nazabadioko, New acylated flavonol glycosides from the aerial parts of Gouania longipetala, Phytochem. Lett. 11 (2015) 306-310.

[31] A. Benmerache, M. Benteldjoune, A. Alabdul Magid, A. Abedini, D. Berrehal, A. Kabouche, S.C. Gangloff, L. Voutquenne-Nazabadioko, Z. Kabouche, Chemical composition, antioxidant and antibacterial activities of aerial parts of Tamarix balansae J. Gay, Nat. Prod. Res. 10 (2017) 1-8.

[32] A. Benmerache, A. Alabdul Magid, D. Berrehel, A. Kabouche, L. VoutquenneNazabadioko, S. Messaili, A. Abedini, D. Harakat, Z. Kabouche, Chemical composition, antibacterial, antioxidant and antityrosinase activities of glycosides from aerial parts of Eryngium tricuspidatum L., Phytochem. lett. 18 (2016) 23-28.

[33] P. Sientzoff, J. Hubert, C. Janin, L. Voutquenne-Nazabadioko, J.H. Renault, J.M. Nuzillard, D. Harakat, A. Alabdul Magid, Fast identification of radical scavengers from Securigera varia by combining ${ }^{13} \mathrm{C}$ NMR-based dereplication to bioactivity-guided fractionation, Molecules 20 (2015) 14970-14984.

[34] Y. Wu, Y. Yin, Y. Li, F. Guo, G. Zhu, Secoiridoid/iridoid subtype bis-iridoids from Pterocephalus hookeri, Magn. Reson. Chem. 52 (2014) 734-738. 
[35] Y.M. Zhao, Y.P. Shi, Phytochemicals and biological activities of Dipsacus species, Chem. Biodivers. 8 (2011) 414-430.

[36] X.Y. Tian, Y.H. Wang, H.Y. Liu, S.S. Yu, W.S. Fang, On the chemical constituents of Dipsacus asper, Chem. Pharm. Bull. 55 (2007) 1677-1681. 
Table 1.

Antimicrobial activity of $70 \%$ ethanol extract of S. stellata and fractions A-E (solid medium).

\begin{tabular}{|c|c|c|c|c|c|c|c|c|c|}
\hline Micro-organisms & $\begin{array}{c}70 \% \text { EtOH extract } \\
\mathrm{MIC}(\mathrm{mg} / \mathrm{mL})\end{array}$ & \multicolumn{5}{|c|}{$\begin{array}{c}\text { Fractions } \\
\text { MIC }(\mathrm{mg} / \mathrm{mL})\end{array}$} & \multicolumn{3}{|c|}{$\begin{array}{l}\text { Positive controls } \\
\text { MIC }(\mu \mathrm{g} / \mathrm{mL})\end{array}$} \\
\hline \multicolumn{10}{|l|}{ Gram positive bacteria } \\
\hline Enterococcus faecalis ATCC 1034 & $>10$ & $>10$ & 1.2 & 2.5 & 10 & $>10$ & 16 & $>64$ & NT \\
\hline Staphylococcus aureus 8325-4 & $>10$ & $>10$ & 0.6 & 1.2 & 10 & $>10$ & 0.5 & 4 & NT \\
\hline Staphylococcus aureus CIP 53.154 & $>10$ & $>10$ & 0.6 & 1.2 & 10 & $>10$ & 4 & $>64$ & NT \\
\hline Listeria innocua & $>10$ & $>10$ & $>10$ & 10 & $>10$ & $>10$ & 0.5 & $\leq 4$ & NT \\
\hline Streptococcus pyogenes & 1.2 & 10 & 1.2 & 2.5 & 5 & 5 & 2 & 1 & NT \\
\hline \multicolumn{10}{|l|}{ Gram negative bacteria } \\
\hline Escherichia coli CIP 54.127 & $>10$ & $>10$ & $>10$ & 10 & $>10$ & $>10$ & $\leq 4$ & $>16$ & NT \\
\hline Enterobacter cloacae & $>10$ & $>10$ & $>10$ & 10 & $>10$ & $>10$ & $\leq 4$ & $>16$ & NT \\
\hline Providencia stuartii & $>10$ & $>10$ & $>10$ & 10 & $>10$ & $>10$ & 2 & $>64$ & NT \\
\hline Pseudomonas aeruginosa ATCC 9027 & $>10$ & $>10$ & $>10$ & 10 & $>10$ & $>10$ & 8 & $>64$ & NT \\
\hline Shigella sonnei & $>10$ & $>10$ & $>10$ & 10 & $>10$ & $>10$ & 0.5 & 8 & NT \\
\hline \multicolumn{10}{|l|}{ Yeast } \\
\hline Candida albicans & 5 & 10 & 0.6 & 1.5 & 5 & 10 & $>64$ & $>64$ & 0.5 \\
\hline Candida glabrata & 2.5 & 10 & 2.5 & 2.5 & 10 & 10 & $>64$ & $>64$ & 0.25 \\
\hline Candida tropicalis & 5 & $>10$ & 1.5 & 1.5 & 5 & 10 & $>64$ & $>64$ & 0.25 \\
\hline Candida kefyr & 2.5 & 5 & 1.2 & 1.2 & 5 & 5 & $>64$ & $>64$ & 0.25 \\
\hline Cryptococcus neoformans & 2.5 & 5 & 1.2 & 1.2 & 5 & 5 & $>64$ & $>64$ & 0.5 \\
\hline
\end{tabular}

MIC: minimum inhibitory concentration, NT: not tested. Positive controls: G: Gentamicin, V: Vancomycin and Am: Amphotericin B.

Table 2. DPPH radical scavenging and mushroom tyrosinase inhibition of $70 \% \mathrm{MeOH}$ extract, fractions A-E and compounds isolated from S. stellata.

\begin{tabular}{|l|c|c|}
\hline & $\begin{array}{c}\text { DPPH radical scavenging activity } \\
\mathrm{IC}_{50}(\mu \mathrm{g} / \mathrm{mL})\end{array}$ & $\begin{array}{c}\text { Mushroom tyrosinase inhibition } \\
\mathrm{IC}_{50}(\mu \mathrm{g} / \mathrm{mL})\end{array}$ \\
\hline F0\% MeOH extract & $86.0 \pm 1.8$ & $(40 \%)^{*}$ \\
Fraction A & $133 \pm 2.6$ & $(45 \%)^{*}$ \\
Fraction B & $48.7 \pm 1.1$ & $(15 \%)^{*}$ \\
Fraction C & $25.0 \pm 0.8$ & $1330 \pm 23$ \\
Fraction D & $64.3 \pm 1.5$ & $1000 \pm 19$ \\
Fraction E & $>200$ & $1330 \pm 22$ \\
$\mathbf{6}$ & $7.1 \pm 0.4$ & $>665$ \\
$\mathbf{7}$ & $7.2 \pm 0.4$ & $>665$ \\
$\mathbf{8}$ & $8.5 \pm 0.5$ & $>665$ \\
$\mathbf{1 0}$ & $16.0 \pm 0.6$ & $>665$ \\
Ascorbic acid & $6.3 \pm 0.1$ & $6.8 \pm 0.1$ \\
Kojic acid $^{\mathrm{a}}$ & & \\
\hline
\end{tabular}

*\% Inhibition at $1330 \mu \mathrm{g} / \mathrm{mL}$.

${ }^{a}$ The positive control. 
Table 3

NMR spectroscopic data of the compounds 1-2 in $\mathrm{CD}_{3} \mathrm{OD}$

\begin{tabular}{|c|c|c|c|c|}
\hline \multicolumn{3}{|c|}{1} & \multicolumn{2}{|l|}{2} \\
\hline \multicolumn{2}{|r|}{$\delta_{\mathrm{H}} \mathrm{m}(J$ in $\mathrm{Hz})$} & $\delta_{\mathrm{C}}$ & $\delta_{\mathrm{H}} \mathrm{m}(J$ in $\mathrm{Hz})$ & $\delta_{\mathrm{C}}$ \\
\hline Unit A & & & & \\
\hline $1 \mathbf{a}$ & $5.60 \mathrm{~d}(6.5)$ & 96.3 & $5.60 \mathrm{~d}(6.5)$ & 96.3 \\
\hline $\mathbf{3 a}$ & $7.43 \mathrm{~s}$ & 151.3 & $7.42 \mathrm{~s}$ & 151.2 \\
\hline $4 \mathbf{a}$ & - & 110.4 & - & 110.3 \\
\hline $5 \mathbf{a}$ & $2.95 \mathrm{q}(6.2)$ & 30.1 & $2.95 \mathrm{q}(6.2)$ & 30.3 \\
\hline $\mathbf{6 a}$ & 1.92 ddd $(13.8,7.8,6.6)$ & 28.9 & $1.92 \mathrm{ddd}(13.8,7.5,6.8)$ & 28.9 \\
\hline $7 \mathbf{a}$ & $\begin{array}{l}4.21 \mathrm{~m} \\
4.26 \mathrm{~m}\end{array}$ & 62.7 & $\begin{array}{l}4.21 \mathrm{~m} \\
4.26 \mathrm{~m}\end{array}$ & 62.7 \\
\hline $\mathbf{8 a}$ & 5.84 ddd $(17.3,10.3,8.7)$ & 134.3 & 5.82 ddd $(17.3,10.5,8.0)$ & 134.3 \\
\hline $9 \mathbf{a}$ & $2.72 \mathrm{~m}$ & 44.0 & $2.71 \mathrm{dt}(8.0,6.2)$ & 44.0 \\
\hline $10 \mathbf{a}$ & $\begin{array}{l}5.30 \mathrm{~d}(10.3) \\
5.36 \mathrm{~d}(17.3)\end{array}$ & 118.2 & $\begin{array}{l}5.30 \mathrm{~d}(10.5) \\
5.36 \mathrm{~d}(17.3)\end{array}$ & 118.2 \\
\hline $\begin{array}{l}\text { 11a } \\
\text { 1a-O-glc }\end{array}$ & - & 167.8 & - & 167.8 \\
\hline $\mathbf{1}^{\prime}$ & $4.74 \mathrm{~d}(7.9)$ & 96.8 & $4.74 \mathrm{~d}(7.9)$ & 98.8 \\
\hline $2^{\prime}$ & $3.23 \mathrm{t}(8.0)$ & 73.3 & $3.23 \mathrm{t}(8.0)$ & 73.3 \\
\hline $\mathbf{3}^{\prime}$ & $3.39 \mathrm{t}(8.8)$ & 76.6 & $3.39 \mathrm{t}(9.0)$ & 76.6 \\
\hline $4^{\prime}$ & $3.29 \mathrm{t}(8.9)$ & 70.2 & $3.29 \mathrm{t}(9.5)$ & 70.2 \\
\hline $\mathbf{5}^{\prime}$ & $3.33 \mathrm{~m}$ & 76.9 & $3.33 \mathrm{~m}$ & 76.9 \\
\hline $6^{\prime}$ & $3.68 \mathrm{dd}(12.0,5.6)$ & 61.4 & $3.68 \mathrm{dd}(12.0,5.6)$ & 61.4 \\
\hline & $3.92 \mathrm{dd}(12.0,2.2)$ & & $3.92 \mathrm{dd}(12.0,2.2)$ & \\
\hline & 7a-O-caffoyl & & 7-O-p-Coumaryol & \\
\hline $1^{\prime \prime}$ & - & 126.3 & - & 125.7 \\
\hline $2^{\prime \prime}$ & $7.05 \mathrm{~d}(2.0)$ & 113.7 & $7.47 \mathrm{~d}(8.6)$ & 129.8 \\
\hline $3^{\prime \prime}$ & - & 145.4 & $6.83 \mathrm{~d}(8.6)$ & 115.4 \\
\hline $4^{\prime \prime}$ & - & 148.2 & - & 148.2 \\
\hline $5^{\prime \prime}$ & $6.80 \mathrm{~d}(8.1)$ & 115.1 & $6.83 \mathrm{~d}(8.6)$ & 115.4 \\
\hline $6^{\prime \prime}$ & $6.96 \mathrm{dd}(8.1,2.0)$ & 121.6 & $7.47 \mathrm{~d}(8.6)$ & 129.8 \\
\hline $7^{\prime \prime}$ & $7.55 \mathrm{~d}(16.0)$ & 145.5 & $7.61 \mathrm{~d}(16.0)$ & 145.1 \\
\hline $8^{\prime \prime}$ & $6.24 \mathrm{~d}(16.0)$ & 113.7 & $6.30 \mathrm{~d}(16.0)$ & 113.8 \\
\hline $9^{\prime \prime}$ & - & 167.9 & - & 167.9 \\
\hline Unit B & & & & \\
\hline $1 b$ & $5.28 \mathrm{~d}(5.3)$ & 96.3 & $5.28 \mathrm{~d}(5.3)$ & 96.3 \\
\hline $\mathbf{3 b}$ & $7.53 \mathrm{~s}$ & 152.3 & $7.53 \mathrm{~s}$ & 152.3 \\
\hline $4 b$ & - & 111.6 & - & 111.7 \\
\hline $5 \mathbf{b}$ & $3.14 \mathrm{q}(8.2)$ & 31.5 & $3.14 \mathrm{q}(8.2)$ & 31.5 \\
\hline $\mathbf{6 b}$ & $\begin{array}{l}1.76 \text { ddd }(13.8,8.2,5.1) \\
2.34 \text { dd }(13.8,8.1)\end{array}$ & 38.9 & $\begin{array}{l}1.76 \mathrm{ddd}(13.5,8.0,5.2) \\
2.34 \mathrm{dt}(13.8,8.0)\end{array}$ & 38.9 \\
\hline $7 \mathbf{b}$ & $5.24 \mathrm{t}(5.1)$ & 77.0 & $5.24 \mathrm{t}(4.5)$ & 77.0 \\
\hline $\mathbf{8 b}$ & $2.19 \mathrm{~m}$ & 39.7 & $2.16 \mathrm{~m}$ & 39.7 \\
\hline $9 b$ & $2.08 \mathrm{~m}$ & 45.7 & $2.08 \mathrm{~m}$ & 45.7 \\
\hline $10 b$ & $1.10 \mathrm{~d}(6.9)$ & 12.6 & $1.10 \mathrm{~d}(6.9)$ & 12.6 \\
\hline $11 b$ & - & 166.9 & - & 166.9 \\
\hline $\mathrm{OCH}_{3}$ & $3.68 \mathrm{~s}$ & 50.3 & $3.68 \mathrm{~s}$ & 50.3 \\
\hline 1b-O-glc & & & & \\
\hline $\mathbf{1}^{\prime \prime \prime}$ & $4.68 \mathrm{~d}(7.9)$ & 96.8 & $4.68 \mathrm{~d}(7.9)$ & 98.7 \\
\hline $2^{\prime \prime \prime}$ & $3.23 \mathrm{t}(8.0)$ & 73.2 & $3.23 \mathrm{t}(8.0)$ & 73.2 \\
\hline $3^{\prime \prime \prime}$ & $3.39 \mathrm{t}(9.0)$ & 76.6 & $3.39 \mathrm{t}(9.0)$ & 76.6 \\
\hline $4^{\prime \prime \prime}$ & $3.31 \mathrm{t}(8.8)$ & 70.1 & $3.31 \mathrm{t}(8.8)$ & 70.1 \\
\hline $5^{\prime \prime \prime}$ & $3.33 \mathrm{~m}$ & 77.0 & $3.33 \mathrm{~m}$ & 77.0 \\
\hline $6^{\prime \prime \prime}$ & $3.68 \mathrm{dd}(12.0,5.6)$ & 61.4 & $3.683 .68 \mathrm{dd}(12.1,5.6)$ & 61.4 \\
\hline & $3.92 \mathrm{dd}(12.0,2.2)$ & & $3.92 \mathrm{dd}(12.1,2.0)$ & \\
\hline
\end{tabular}


Table 4.

Minimum inhibitory concentration (MIC) values of compounds isolated from S. stellata in liquid medium. ${ }^{\mathrm{a}}$

\begin{tabular}{|c|c|c|c|c|c|}
\hline & \multicolumn{5}{|c|}{ MIC $(\mu \mathrm{g} / \mathrm{mL})$} \\
\hline Compounds & E. faecalis (ATCC 1054) & S. aureus (CIP53.154) & E. coli (CIP 54.127) & S. epidermis & P. aeruginosa (ATCC9027) \\
\hline 1 & 31.2 & 62.5 & 250 & 31.2 & 125 \\
\hline 2 & 31.2 & 62.5 & 125 & 31.2 & 125 \\
\hline 3 & 500 & 62.5 & 62.5 & 125 & 125 \\
\hline 4 & 125 & 250 & 500 & 250 & 250 \\
\hline 6 & 62.5 & 62.5 & 125 & 250 & 125 \\
\hline 8 & 125 & 250 & 125 & 125 & 125 \\
\hline 9 & 250 & 250 & 125 & 125 & 125 \\
\hline 11 & 250 & 250 & $>500$ & 250 & 125 \\
\hline 12 & 125 & 125 & 500 & 125 & 62.5 \\
\hline
\end{tabular}

${ }^{a}$ No bacterial growth inhibition observed in bioautography assay for compounds 5, 7 and $\mathbf{1 0}$. 

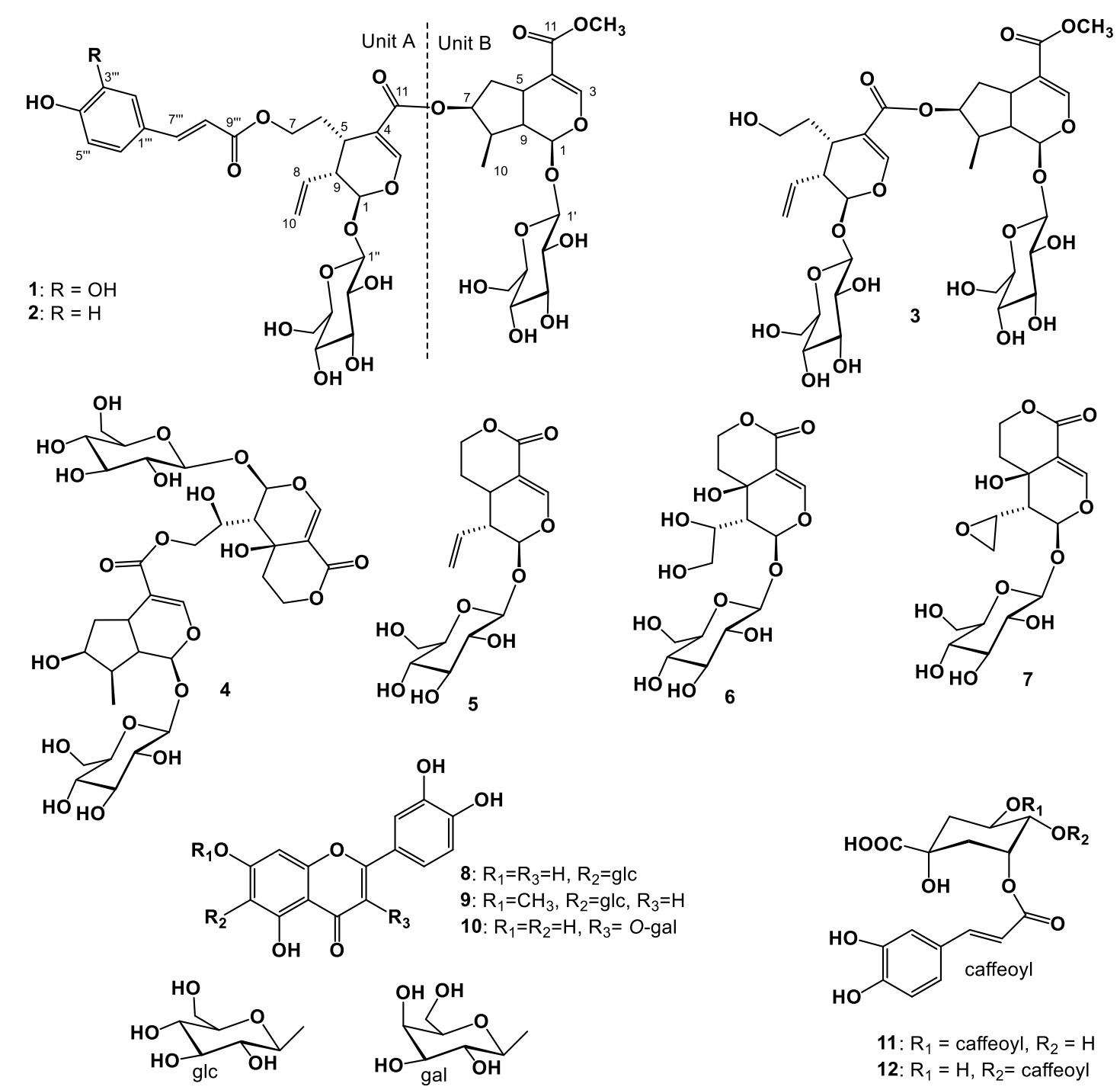

11: $R_{1}=$ caffeoyl, $R_{2}=H$ 12: $R_{1}=H, R_{2}=$ caffeoyl

Figure 1. Chemical structures of compounds 1-12 isolated from Scabiosa stellata. 

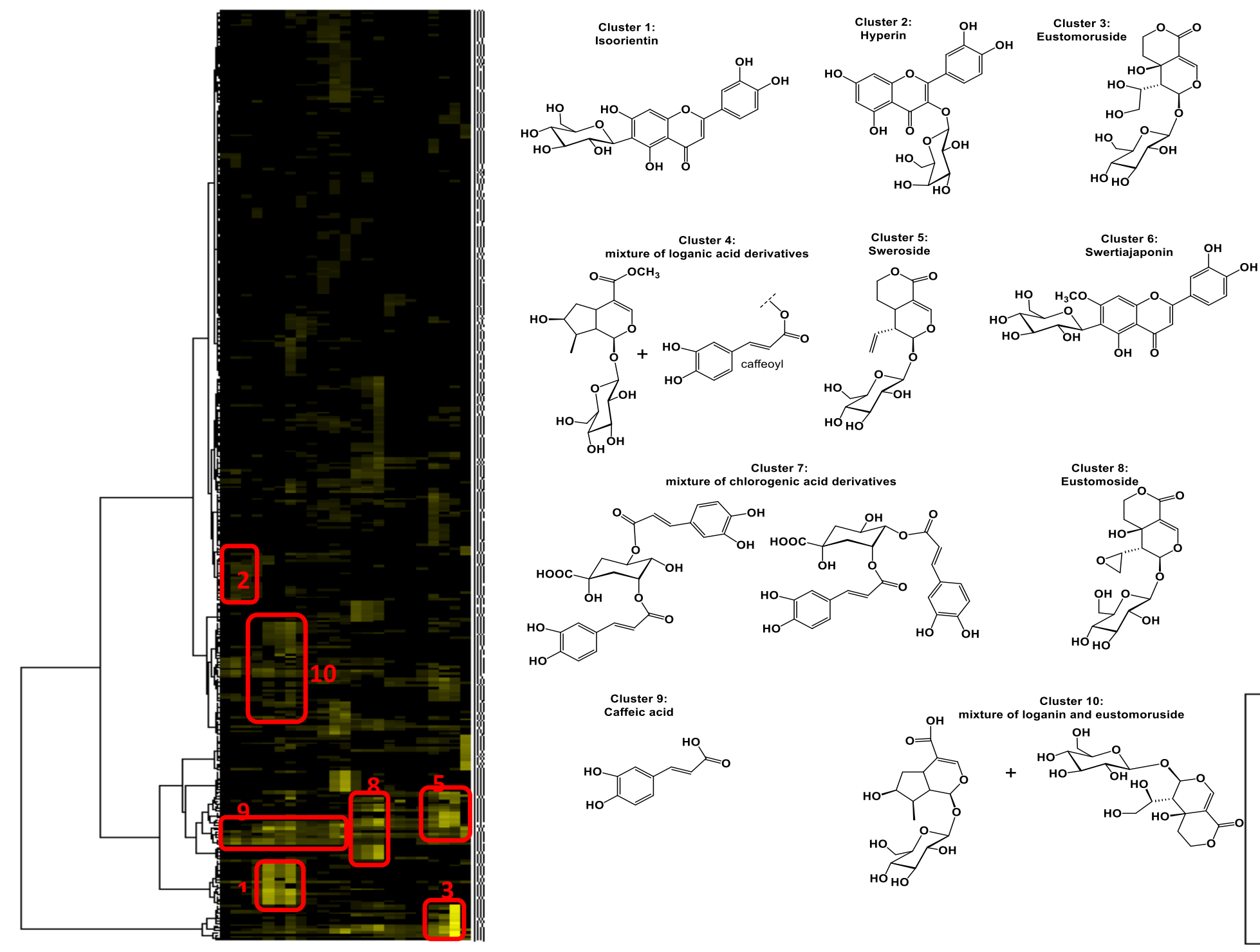

Fig. 2. ${ }^{13} \mathrm{C}$ NMR chemical shift clusters obtained by applying HCA on CPC fractions B (left) and C (right) of Scabiosa stelatta. 
